\title{
From Renunciation to Nirvana and Beatitude: What Is Common in Buddha and Christ?
}

\author{
Sabindra Raj Bhandari, PhD \\ Department of English, Prithvi Narayan Campus, Pokhara, Nepal
}

\begin{abstract}
Article History: Submitted 13 February 2021; Reviewed 15 April 2021; Accepted 21 April 2021 Corresponding Author: Sabindra Raj Bhandari, Email: bhandarisabindra@gmail.com DOI: https://doi.org/10.3126/paj.v4i0.37018

Copyright 2021 (C) Author/s and Centre for Research and Innovation. This work is licensed under a Creative Commons Attribution 4.0 International (CC BY 4.0) License.
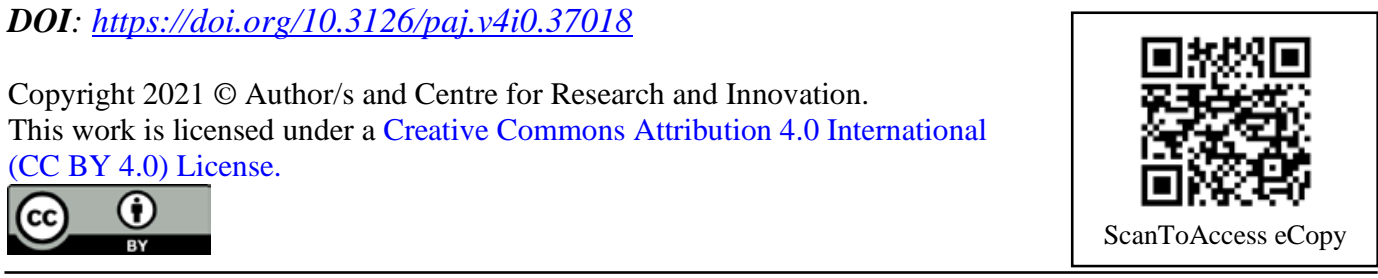

\begin{abstract}
This article explores the confluence in the ideas that Buddha postulated in the Dhammapada and Christ in the gospels of Mathew, Mark, Luke and John in the New Testament. In spite of the differences in their context, arena, and even in trends and tenets, they both project that the renouncement in action lead the worldly affairs to the realm of spiritual illumination. Both the Dhammapada and the four gospels from the New Testament clearly proclaim that subtraction of the ego along with the pursuit of wisdom eventually open the path of inner evolution for redemption-Nirvana and Beatitude. Likewise, the concepts of Bodhisattva and Messiah have similar mission to redeem the humanity. All these concepts invite a new revisiting to qualify them, adding a new in-depth insight. This fresh revisit widens new dimensions to view the meeting points between the seemingly diverse religious philosophies. Therefore, this paper has applied the qualitative approach to the ideas from the divine creations-the Dhammapada and the gospels of Mathew, Mark, Luke and John from the New Testament.
\end{abstract}

KEYWORDS: Beatitude, Buddha, Christ, evolution, Nirvana, renouncement

\section{INTRODUCTION}

This article explores the confluence in the major philosophical issues between the two great figures of human civilization-Buddha and Christ. They belonged to different epochs, cultures and geography, and were not certainly alike in all situations. However, the Dhammapada from Buddha and four gospels-namely Mathew, Luke, Mark, and John - in the New Testament deliver the similar messages in their essence. The philosophies of renunciation, Nirvana and Beatitude express similar voices and ideas. When Buddha was born about the mid-sixth century B.C. (563 B. C), in present day Nepal at Kapilbastu district, the Indian civilization was at its peak. The whole Indian subcontinent was guided by the Hindu scriptures and Hindu faith. The ritual practices of brahmanism were guiding the religious practises. Rig Veda, the oldest Hindu scripture, dated back at least to fifteen hundred B.C., remained as the major landmark for the 
growth and rise of Vedic Santana Dharma (the eternal religion). The great saying from the Rig Veda, "Truth is one, the wise call it by many names" (as cited in Goldberg, 2010, p. 10) perhaps became the main current of that society. There was another great current ruling at that times, namely the practice of cosmic speculations which is known to be the trend of Vedanta - the philosophical teaching of the Vedas. This great tradition was esoteric in essence unlike the Vedic exoteric pattern of ritual Hindu practice for earthly glories. This sub-current postulated the spiritual evolution within the human, focussing that the divinity is within us.

The Buddha was a keen observer of his age. He became the reactionist to the first exoteric practices of Vedic rituals and sacrificial tendencies. The tradition of selfrealization of Upanishads and its major propagation of the inner self evolution found their deep voices in him. He sought to give emphasis, as Easwaran (2015) writes, "on direct experience in meditation without reference to any outside authority, and a passionate trust in truth, in oneness of life, and in our human capacity to take our destiny into our own hands - all these are very sprit of the Upanishads and no one embodies better than the Buddha" (p. 27) . Therefore, the Buddha directed the journey to inwardness because of the prevailing Upanishadic trend of Vedanta that postulated for the cosmic speculation and the nature of reality.

Christ was born in the present day Israel at Bethlehem. Much of his history is still mysterious. However, as stated in Mathew Gospel, his mother was Mary and father was Joseph. Some miraculous events happened during his birth. Kersten (2001) states that over ten thousand monographs have since been written about Christ; still he remains as a mysterious figure. Though there is no exact date of his birth, possible years ranged from the seventh to the fourth years before the change from B.C to A.D. Moreover, he goes on to claim that the Christ was certainly born during the reign of Herod, who died four years before the 'Christian era,' that is in 4 B.C. (p. 20). In the four gospels of New Testament, his childhood has been ignored. Only we can see some traces of his visit to Jerusalem. He was just twelve at that time (Luke, 1:4). Then, he was presented at the age of thirty while taking the baptism by John the Baptist (Luke, 3: 21). The mysterious aspect of him is the elapse of those eighteen years of his life. However, historians agree that he was crucified in 30 A.D. He was a Jew and a keen observer of the Jewish tradition. He claimed himself as a reformer. He was there to improve the strict and dogmatic practise of Jews and Judaism.

Born at different time, space and geography, both of them seem to be incomparable in their ideas as they regulated for the human kind. Showing the differences between the two creeds they have postulated, Osborne (2009) views that "In temperament, there is an utter difference between the two, Christianity is completely devotional and dualistic while Buddhism is metaphysical and advaitic” (p.131). However, they have so many things in common.

\section{REVIEW OF LITERATURE}

Despite the fact that Buddha and Christ belong to different contexts and time, their words resound the same tunes. It would be really wonderful to perceive the unity in diversity between these two great divine persons. Christ postulates his entire philosophy in the Sermon on the Mount in the New Testament. Similarly, the Dhammapada holds the entire philosophy of Buddha. Showing the similarities between the two, Easwaran (2015) writes:

If all of the New Testament had been lost; it has been said, and only the Sermon on the Mount had managed to survive these two thousand years of history, we would still have all that is necessary for following the teaching of Jesus the 
Christ. . . . If everything were lost, we would need nothing more than the

Dhammapada to follow the way of the Buddha. (p.13)

Easwaran clearly acknowledges the importance of Sermon on the Mount of Jesus and the Dhammapada of the Buddha. Still, he does not acknowledge the echoes of themes that revolve round these two great heritages of the entire human history.

Kersten (2001) has clearly detected tunes of ideas and philosophy in his book Jesus lived in India between Buddha and Christ. He writes, "Affinities between the ethical teachings of Jesus and of Buddha are well known. Both forbid murder, theft, bearing false witness and illicit sexual relations. ... The parallels are many, and some texts of both faith coincide virtually word for word" (p.119). However, Kersten simply generalizes the concepts of morality and ethics, yet the philosophical coalescence in these great works remains to be crystallized. They belong to different legacies. Still, there remain lots of similarities while possessing their legacies of their own. Goldberg (2010) clarifies:

Their compatibility makes sense, given that Buddhism is part of the Vedic legacy. Siddhartha Gautama, the man we call Buddha, was brought up in northern India and became a classic renunciate-a yogi, if you will. He was a reformer, much as Jesus was a reformer of the Hebraic tradition, and the religion that developed in his name stands in relation to Hinduism as Christianity does to Judaism. Also, like Christianity, Buddhism became entrenched in foreign lands even as it faded in its place of origin. (p. 5)

The development of these philosophical schools bears the similar trends. The ways they developed and flourished bear the exact resemblances.

Scholars like Prasad (2004) simply shows the resemblance of their birth: "It is not a little strange that the remarkable resemblance, which we have noticed between Buddhism and Christianity extends even to the lives of their founders. Gautama Buddha, as well as Jesus Christ, is said to have been miraculously born" (as cited in Acharya, 2004, p. 309). The point here remains to be considered that there happens the great amalgamation in the ideas between the two as mentioned here: "Although the story and ideology have changed over the centuries and millennia, numerous elements of Buddhism closely resemble the Christian myth and ideology" (Acharya, 2004, p. 308). The great confluence has been noted in general terms. However, it demands a thorough and detailed study while considering the similar concepts and ideas that hide in the Sermon on the Mount including the four gospels of Christianity and the Dhammapada.

\section{STATEMENT OF PROBLEM}

Both the Dhammapada and the major gospels from the New Testament project the religion of humanity, love and faith to transcend this phenomenal world for spiritual illumination. They postulate the idea of the divinity in self. The concepts of renunciation, Nirvana, and Beatitude resound the exact echoes of different voices. They pave the way for spiritual evolution. Thus, the present article answers the following research questions:

a) What are the concepts of renouncement, Nirvana, and Beatitude both Buddha and Christ postulate in the Dhammapada and Sermon on the Mount, including the gospels of Mathew and Luke?

b) Why do these concepts coalescence with each other?

c) How do they project their ideas for spiritual illumination and the selfevolution? 


\section{OBJECTIVES}

The present study intends to show the confluence between these two seemingly diverse philosophical schools of religious thoughts. The article also aims to show how these two religious thoughts play the similar vibrations of musical tunes while showing the unity in diversity.

\section{METHODOLOGY}

The research method used in this article is exploratory and interpretative. In order to address the issues in questions, the concepts and themes from the Dhammapada and the gospels of Mathew and Luke from the New Testament have been taken as the primary sources of ideas related to renouncement, faith, love and spiritual illumination. The themes of humanity, love and faith related to renouncement and the path for spiritual evolution underlying in the concept of Nirvana and Beatitude from both works have been compared, explored, interpreted and expounded to show the co-relation between the Buddha and the Christ. The article adopts a thematic analysis method to revisit these great works. In the same way, this article also reveals how the themes from these works match each other. Related secondary sources such as reviews have been considered to justify the fact that these philosophical texts have universal ideas in common. The subsequent sections provide an insightful union between the Dhammapada and the main four gospels from the New Testament.

\section{RENOUNCEMENT OF BUDDHA AND CHRIST}

Buddha and Christ speak for inner evolution. They magnify the little essence. The way they speak is not for themselves, but for others. Their words are to be reflected and meditated. They both talk about deep faith and love. Renouncing the world ultimately leads to spiritual illumination. The more one attaches to the worldly things, the more one hoards the pains and tribulations. The attachment brings the series of reactions which become the source of pains. Buddha says in the Dhammapada:

But those who have purified their minds, who are endowed with truth and self-control, are truly fit to weak the saffron robe.

Those who are selfish suffer here and here after; they suffer in both worlds from the result of their own actions. But those who are selfish rejoice here and rejoice here after. They rejoice in both worlds from the results of their actions.

But those who are selfish rejoice in this life and in the next. They rejoice seeing the good that they have done, and more joy awaits them in the life. (Trans. Easwaran, 2015, pp. 106-107)

Buddha projects the ideas that to be liberated, one should be free from the craving desires. The renouncement in mind is great, not the renouncement in body. It brings purity. The purity of mental state counts the value; it brings spiritual evolution. Attachments to the gross material objects develop ego, which gives rise to the desires. On the other hand, subtraction from the ego leads to the ultimate path of selfless action. Then there is no bondage to confine oneself; one is liberated within. Nothing remains there to affect him/her.

The above lines form that the whole universe is just replete with action. We are here to conduct action without being affected by the profit oriented attitude. The action is the cause; whatever cause is planted so is reaped later. This is the law of universe known as the law of karma (action). To be liberated from this cycle is just to watch it without being involved in it, wishing for the consequences the action bears. The action conducted 
without selfish motive always leads us to the higher plane. It is only possible by acting with a pure motive of just simply conducting the action without paying any attention for personal gratification. Then a person feels and thinks the whole world in oneself and oneself in the world. This stage of attitude brings harmonious assimilation between the personal consciousness and the cosmic one. Then one is free and liberated who can rise beyond the cycle of cause and effect. This is the way of spiritual liberation that is just the outcome of performing action without bearing its fruits.

Buddha suggests the seeker to transcend the worldly gratification. He talks for the self-pilgrimage; a state of beatitude, blessedness and a state of perfection. That is only the hall mark when one is guided with pure motive. Christ too postulates the same stage of blessedness in those discourses that he delivered in the Sermon on the Mount, which are inscribed in the gospel of Mathew:

Blessed are the poor in spirit,

For theirs is the kingdom of heaven.

Blessed are those who mourn,

For they will be comforted.

Blessed are the meek,

For they will inherit the earth.

Blessed are those who hunger and thirst for righteousness,

For they will be filled.

Blessed are the merciful,

For they will be shown mercy.

Blessed are the pure in heart,

For they will see God.

Blessed are the peacemakers,

For they will be called sons of God

Blessed are those who are persecuted because of righteousness,

For theirs is the kingdom of heaven. (Mathew, 5:3-10)

Being the best preaching of Christ, these sonorous symbolic lines project the grand essence of Christianity. These sermons from the very beginning state the blessedness of the people "poor in spirit," which means people with religious nature and harmonious tendency. People who are from ego can only mourn for others because they see others in themselves. One who sees no difference between "thisness" and "thatness" is really beyond the pros and cons of this worldly phenomenon. The world becomes one for that person who attains this height. Christ's proclamations in the above lines state such a grand scenario of integration of divisions and differences that remains in the world that we see. He suggests the seeker to eliminate his/her simple earthly glories, selfish motives for the inner evolution. Thus, Doren (1991) rightly admits these sermons as "The most trenchant statement of the new doctrine is contained in Christ's sermon on the Mount" (p. 17). The new doctrine is the doctrine of true renouncement that generates the love, faith, graces and selflessness. Jesus is not only concerning to worldly religion in the Sermon on the Mount. According to Fowler (2006), he may be proclaiming about the spiritual journey that he refers as the kingdom of the god which is not related to any physical dimension of space and time, rather he must be the referring to the spiritual and eternal realm (p 96). These ideas bring Christ very near to Buddha because their proclamations are beyond the gross phenomenal manifestations of the physical world.

The verses from great creations of human history lead for spiritual pilgrimage. They both focus on the dropping of the "ego" the "I-ness." The moment it is stripped, then the divinity opens out. This is the stage of perfection which finds its better 
expression in Echkart's (2009) words; "Thou shalt lose thy thy-ness and dissolve in his his-ness; thy thine shall be his mine, so utterly one mine that thou him shalt know eternalwise his is-ness, free from becoming: his nameless nothingness" (as cited in Osborne, 2009, p. 150). Although Buddha does not believe in personal God; however, he talks about the metaphysical stage of going beyond the phenomenal existence, crossing the desires and attachments.

Both Buddha and Christ postulate the concepts of renouncement in action not of action as well as love and affinity with the world. In the above given verses, they both proclaim that the stage of renouncement is possible only when an individual is guided by the positive vibration that can be able to bind a harmonious relationship with the cosmic manifestation. For this sake, both believe in making of the self. Buddha proclaims: "Our life is shaped by our mind; we become what we think. Suffering follows an evil thought as the wheels of a cart follows the oxen that draw it. Our life is shaped by our mind; we become what we think. Joy follows a pure thought like a shadow that never leaves" (Trans. Easwaran, 2015, p. 105). These great lines signify that an individual is the totality and outcome of thought. The state of mind determines whether one can have the success in the journey of spiritual evolution or not. Exactly in the same tone, Christ also proclaims: "The good man brings good things out of the good stored up in him, and the evil man brings evil things out of the evil stored in him. ... . For by your words you will be acquitted and by your word you will be condemned" (Mathew, 12:35, 37).

Buddha and Christ make a point that whatever you think you act accordingly. Then if your evil thoughts become the guidance of your action, then you fall purely in the web of pain. To purify the thoughts, the concept of "I-ness" should be annihilated. Therefore, "The moment of the feeling of "I" comes to an end; we become the part of divine" (Osho, 2012, p. 107). Then, our personal consciousness becomes the cosmic one. Our name and forms will come to an end as graphically presented by Echkart earlier. What a divine concept of spiritual illumination! In this way, we must examine our life being a perfect actor as Bergson (1997) focuses "To act as men of thought; think as man of action" (as cited in Corliss, 1997, p. 8). This state rises when the door goes beyond the stage of attachment with the true spirit of renouncement. When all actions become the part of total devotion, surrender, worship, and meditation not for the self, but for seeing the self in others and others in self, then a person holds the entire universe. This is the stage of inward journey that surmounts the inner evolution as projected by Buddha and Christ.

They both reject hypocrisy when they speak exactly in the same manner as if it seems spoken by the same person. Buddha says, "The fault of other are clearly observed. But one's own faults are difficult to see. A person winnows the fault of others into prominence like chaff. He hides his own like the bird-hunter who conceals himself with leaves and twigs" (as cited in Thero, n. d., p. 798). These lines give the clear picture of hypocrisy. Here we can find exact tone of Christ in the gospel of Mathew: "Why do you look at the speck of sawdust in your brother's eye and pay no attention to the plank in your own eye? You hypocrite first take the plank out of your own eye and then you will see clearly to remove the speck from your brother's eye" $(7: 3,5)$. What we see is the ramification of desire that turns into the more hypocrisy that is dangerous. Both talk about the purification of mental state that leads us to the downsizing of ego. The more one subtracts, one is very near to the ultimate path of self-realization, illumination, bliss and Nirvana. These powerful lines by Lao Tzu (1997) better summarize the stage:

To pursue the academic, add to it daily.

To pursue the Tao, subtract from it daily.

Subtract and subtract again, 
to arrive at nonaction.

Through nonaction nothing is left undone. (p. 48)

Subtraction and annihilation from the pair of dualities obviously open the path for bliss, redemption, Nirvana so on.

For the renouncement of the world, they both formulate the same parameters for the purification of the mental condition. To awaken the self, one should be free from the passion that the body creates. Buddha says, "For hatred can never put an end to hatred; love alone can. This is unalterable law" (Trans. Easwaran, 2015, p. 105). For him, this is the binding force and eternal law of the "Dhamma," the path of righteousness. Christ too talks in the same way when he says, "If someone strikes you on the right cheek, then turn to him the other also" (Mathew, 5:38). Going beyond the normal rule of hate and love, he says, "Love your enemies, and pray for those who persecute you, then you may be sons of your father in heaven" (Mathew, 5:45). They come with the message of love. Only the positive vibration can have the power to win over the negative ones. They proclaim that negativity could be abolished with the positive message not with the negative ones. One who is above the normal rules of world may have this broader perspective. This is the message that these great humans deliver for the world. Now, let's compare some of verses of the Dhammapada with the Bible. Buddha says:

Avoid all evils, cultivate the good, purify your mind; this sums up the teaching of the Buddha. Do not find fault with others, do not injure others, but live in accordance with the dharma. Be moderate in eating and sleeping, and meditate on the highest. This sums of the teaching of the Buddha. (Trans. Easwaran, 2015, p. 170)

How wonderfully Buddha focuses on the serenity of the mind to control over the passions over the body. He means to say that mind rules over the body. He talks about the purification. More or less, Christ too has the same ideas when he talks about the purification:

What comes out of a man is what makes him 'unclean.' For from within, out of men's hearts, come evil thoughts, sexual immorality, theft, murder, adultery, greed, malice, deceits, lewdness, envy, slander, arrogance, and folly. All these evils come from inside and make a man unclean. (Mark, 7:20, 21, 22, 23)

All of these lines plead for the purity of thoughts to have dominance over the passions that the body promulgates. It is not the flesh that leads to the spiritual evolution; it is the consciousness that opens the path for it. However, the body should be under the total control of the mind. Then the seeker can have spiritual evolution within. Thus, renouncement of the evil, obviously lead to the realm of bliss and eternity.

The stage of self-sacrifice holds a great value for Buddha and Christ. Their divine voices bring the sense that when all the actions rise above the ego perverted frame work, one can see the total renouncement in the action not the renouncement of action. The action becomes spontaneous. The individual attains totality when this quality emerges in the horizon of a person's attitude. Then, "In a spontaneous action the whole being of man is present. In such an action one sees the miracle of the totality present in the unit of the whole inhabiting the part" (Mehta, 2006, p. 48). One is in the stage of totality, a whole. This is the great crux of confluence between Buddha and Christ. Let's examine these sonorous lines from the Dhammapada:

Conquest breads hatred, for the conquered live in sorrow. Let us be neither conqueror nor conquered, and live in peace and joy.

There is no fire like lust, no sickness like hatred, no sorrow like separateness, no joy like peace. No disease is worse than greed, no suffering worse than selfish 
passion. Know this and seek Nirvana as the highest joy. (Trans. Easwaran, 2015, p. 178)

Buddha pleads for the inner journey not the phenomenal one. The purification of the self is the best way for the highest joy that Buddha calls the Nirvana-the blissful stage. There are two chapters (Chapters 25 and 26) in the Dhammapada that are entirely related to the Bhikshu (Monks) and the Brahmin (the educated ones). The entire verses of these two chapters talk that to be liberated; one should renounce the hypocrisy, selfishness, desires, showiness, shallowness, greed, fear and craving desires. The same inner purification also becomes one of the most significant preaching in the gospel of Mathew. Christ says:

Woe to you, teachers of the law and Pharisees, you hypocrites! You clean the outside of the cup and dish, but inside they are full of greed and self-indulgence. ... First clean the inside of the cup and dish, and then the outside will be clean. . . . In the same way, on the outside you appear to people as righteous but on the inside you are full of hypocrisy and wickedness. (Mathew, 23: 25, 26, 28)

How exactly the tones and inner gist of these two come together! They suggest that outward phenomenal existence and the external reality do not hold the same value for the inner purification. Both works merely reject the hypocrisy and the transient glories, and lead us to the redemption and the Nirvana. These two terms have a point of departure. However, they bear the points of significance as they lead to the stage of bliss that transcends the impermanence and transitoriness of these earthly glories. Osborne (2009) gives a clear perspective on this matter. He views that though the identity is not immediately recognizable; the same fundamental doctrine co-exists in both religious philosophies. They both support that the idea the way of strengthening the ego leads to the suffering and alienation from divine grace whereas the surrender of ego leads to the Beatitudes. This is the fundamental of Christianity - being the doctrine of sin and rebellion against God's will, and in Buddhism, it is taught as a pure law of cause and effect: attachments to things causes a person to turn toward them and away from the Bliss of Nirvana (p. 132). They agree that in the renouncement in action not of action surely leads to the inner journey of illumination that Buddha calls Nirvana, and Christ names it as redemption or Beatitude.

\section{NIRVANA AND BEATITUDE, THE ULTIMATE GOAL}

Christianity believes in personal god while Buddhism has nothing to do with it. However, the unification of the seeker with the blissful stage becomes the point of focus for Buddha and Christ. Both of them talk about the union between the seeker and divinity. The intermediary of love, renouncement leads to the inwardness that is the way for the divine unity between the seeker and the ultimate realization. Buddha postulates the basic four noble truths for the way to realize the eternity. For him, the world is transitory and impermanent. Therefore, it is full of dukkha (Suffering). The second noble truth is that the dukkha is the outcome of trishna (craving desire). The third noble truth claims that the dukkha can be ceased when one attains Nirvana. The final truth proclaims that Nirvana can be attained by following the eight fold faiths that Buddha prescribes. Hamilton (2001) summarizes the four noble truths:

The four Noble Truths

Human existence is intrinsically characterised by dukkha.

Dukkha arises because of appetitive craving and desires (negative and positive).

There can be a cessation of dukkha, known as nirvana.

Nirvana is achieved by following the Noble Eight fold paths. (p. 48) 
It is clear that the dukkha is the outcome of desire whether it is positive or negative. Attachments to anything and clinging to this false reality of the world is transitory. When the desires that come out of attachment are not fulfilled, then the life becomes frustrated with full of dukkha. This stage can be transcended by realizing the Nirvana. Buddha beautifully provides the summation of his entire philosophy in the Dhammpada:

All created things are transitory; those who realize this are freed from suffering. This is the path that leads to pure wisdom (Nirvana).

All created things are involved in sorrow; those who realize this are freed from suffering. This is the path leads to pure wisdom (Nirvana).

All states are without self; those who realize this are free from suffering. This is the path that leads to pure wisdom (Nirvana). (Trans. Easwaran, 2015, pp. 205206)

Nirvana is translated here as pure wisdom. Once the seeker understands the source of dukkha, s/he is in perfect realization. The moment we realize that this phenomenal existence is universally characterized by impermanence and not self, we subtract our attachments and clinging to it. When we start a journey of detachment from the attachments, then we cross the threshold of Nirvana-the perfect bliss.

Nirvana is the ultimate realization for Buddha. "The Pali Word Nibbana (Sanskrit Nirvana) is composed of "Ni" and "vana": "Ni" is a particle implying negation. "Vana" means weaving or craving. It is called "Nibbana" in the sense that is a "departure (ni)" from the craving which is called vana, lusting" (Thera Maha, 1992, p. 67). In simple words, it is a quest to detach oneself from the attachment of these worldly phenomena. It is a blowing every negativity out of the thinking process. When once Buddha was asked that what he got after attaining Nirvana; his answer was simple that after attaining it, he simply lost many things. He lost his anger, lust, pride, craving desires, attachment, dishonesty and many such negativity. The process of losing such attitudes is getting the entire bliss. This is what Nirvana proclaims for. Samytta Nikaya, one of the Buddhist scriptures, beautifully clarifies the stage of Nirvana and the eight noble paths to attain it:

Friend Sariputta, it is said "Nirvana, Nirvana," What how is Nirvana?'

"The destruction of lust, the destruction of hatred, the destruction of delusion: this, friend, is called Nirvana.'

And what, friend, is that path, what is the way for the realization of this Nirvana?'

'It is friend this Noble Eight Fold Path; that is, right view, right intention right speech, right action, right livelihood, right effort, right mindfulness, right concentration.

This is the path, friend, this is the way for the realization of this Nirvana. (Benedict, 2009, p. 167)

The noble eighth path is popular as the middle way as it avoids the extremity. It just focuses on the balance, harmony, and tranquil way to have the inward journey of realization. In this sense, the journey starts by detaching the phenomenal existence making a quest of inward blissful stage.

Nirvana is a way to realize the light of wisdom, the ultimate reality. It exactly follows the way that Christ shows: "So watch yourselves" (Luke, 17:3). It, in this way, regularly makes an inward quest by blowing out the lust, sin, and greed that are the outcomes of the craving desires. Moreover, Christ too justifies the way to redemption by surrendering the evil and sins. He further views that "Here it is or There it is because the kingdom of God is within you" (Luke, 17:20). Do not these precepts suggest us to make 
an inner quest? Of course, these great sayings resound Christ's voice to go beyond the phenomenal world with utter faith and love of god. He does not give priority to the possession of flesh, rather the more passion and craving desires are controlled, the more many ways are opened for the seeker because "whoever tries to keep his life will lose it, and whoever loses his life will preserve it" (Luke, 17:33). It means he also suggests to transcend the phenomenal cravings and their outcomes. When he postulates that "I am the way and the truth and life" (John, 14:6), he suggests for the total surrender and dissolution of the self into the other. It is also a means of blowing every gross attachment that emerges out of this body and mind toward the world. This concept reverberates the Nirvana of Buddha. Osborne (2009) rightly notes the great confluence:

There is a cure for suffering; that is to say that there is a state of Divine Beatitude. And there is a path to it. This proclamation of the path is the essential part of every religion. Without that it remains mere theory or, at the best, an unintelligent discipline of life. In Christianity, the doctrine of the path has all the warmth of a personal Redeemer who said: 'I am the way,' in Buddhism it is the Noble Eight Fold way. (p. 135)

The eighth old path leads to the Nirvana. To attain that stage, the perfect belief and faith must be the steps. One needs to blow out all the negativity and positivity of the worldly phenomena. When the sensory perception and thought processes are suspended the seeker rises beyond the transitoriness and impermanence nature of this world. S/he remains unaffected. The duality vanishes, and then only the Nirvana, the perfect silence and the perfect redemption shines. A perfect stage of emptiness: "It is Shunyata, emptiness, only in that there is literally nothing there: "no-thing." But emptiness of process means fullness of being" (Easwaran, 2015, p. 97). For Christ, this is only possible with the divine grace. It is the stage of perfect redemption. This stage shines only when one maintains the total stage of faith with one pointedness, which helps to go beyond attachments.That one pointedness is also the key aspect of Nirvana. In this crux of Christ's idea, philosopher Panikkar (2009) "reads the kenosis of Christ, selfemptying, in terms of the sunyata and nirvana of Buddhism" (as cited in Costa, 2009, p. 13). Only, the exemplifications and forms differ, but in the essence they produce the same beat of the tunes.

Christ focuses on one pointedness of faith. He says, "Enter through the narrow gate. For wide is the gate and broad is the road leads to destruction, and many enter through it. But small is the gate and narrow the road that leads to life, and only a few find it" (Mathew, 7: 13, 14). It is sure that Christ here talks about one pointedness and unidirectional way. The more there is distraction, the more is confusion, which leads to astray. Only with the faith in God can lead us to the eternity. However, Buddha does not have belief in this concept. Anyway, that concept of eternity, going beyond this existence, holds us the same over tunes in Buddha and Christ. For eternity, spiritual guidance, moral discipline and self- reliance are needed. In addition, this point is the crux of merge between Buddha and Christ that they are the guide and way to lift up the seeker from this hollow existence - Buddha in the form of Bodhisattva and Christ as Messiah.

\section{CONCLUSION}

Buddha and Christ belong to different dimensions of time, culture, and age. It is very interesting to acknowledge that despite the differences, they bear many similarities. The more interesting is that it has been really wonderful to view the great confluence in their ideas that these two divine human beings postulated. The theme of renouncement for the inner quest and for the spiritual evolution really bring together. They focus on the 
renouncement in actions, passions and gross dualities that run here in the manifested world. The concept of union of this self with the cosmic one is the way of attaining the Nirvana or Salvation. This point proves a point of great coalescence in between them. Buddha's Nirvana and Christ's redemption are the ultimate stages to go beyond the phenomenal existence that is confined by both and decay. Only they differ in the use of symbols and images, but in the underlying pattern, their messages merge and amalgamate. Both of them preach for the subtraction from this transient existence and seek for the eternity. Whether it is Nirvana of Buddha or God's Kingdom for the Christ, both of them realize that Nirvana and God's Kingdom are within us. One needs to seek and start an evolutionary journey within. This is the greatest message for the inner transformation. Likewise, Bodhisattva and Messiah have the same purpose and destination. They both selflessly deny their eternity and join the society. They remain as faithful guides and until and unless the way Nirvana and salvation do not open for the entire creatures. Only, the enlightened ones and a redeemer can do that. The way of renouncement to seek infinity and the concept of sacrifice related to Bodhisattva and Messiah really bring them together. Both of them preach to accept the dualities choicelessly to embrace the whole. The moment totality is accepted; the radiance of eternity flows unimpeded. One realizes Nirvana and the Beatitude; then Buddha's and Christ's voices enchant this dreaming earth forever.

\section{REFERENCES}

Acharya, S. (2004). Suns of god, Krishna, Buddha and Christ unveiled. Adventures Unlimited Press. www.adventuresonlimitedpress.com

Benedict, G. (2009). Buddhist wisdom. Watkins Publishing.

Corliss, L. (1997). The philosophy of humanism. Humanist Press.

Costa, G. D. (2009). Christianity and the world religions. Wiley-Blackwell.

Doren, C. V. (1991). A history of knowledge. Ballantine Books.

Easwaran, E. (Trans.). (2015). The Dhammapada. Jaico.

Fowler, J. A. (2006). A commentary on the four gospels: Jesus confronts religion. C. I. Y. Publishing.

Goldberg, P. (2010). American veda. Three River Press.

Hamilton, S. (2001). Indian philosophy: A very short introduction. Oxford University Press.

Kersten, H. (2001). Jesus lived in India. Penguin.

Maha Thera, Ven. N. (1992). A manual of Buddhism. The Buddhist Missionary Society.

Mehta, R. (2006). From mind to super-mind. Motilal Banarsidass.

Osborne, A. (2009). Buddhism and Christianity in the light of Hinduism. Sri Ramanasramam.

Osho. (2012). Gita Darshan. Full Circle.

The Holy Bible (1984). New International Version, International Bible Society.

Thero, Ven. W. S. (n. d.). Treasury of truth, illustrated dhammapada. The Corporate Body of the Buddha Educational Foundation. www.buddhanet.net

Tzu, L. (1997). The Tao of power (R. L. Wing, Trans). Thorsons.

Woodhead, L. (2014). Christianity: A very short introduction. Oxford University Press. 